\title{
FALLING HOUSE PRICES AND LABOR MOBILITY: EVIDENCE FROM MATCHED EMPLOYER-EMPLOYEE DATA
}

by

\author{
Christopher F. Goetz \\ U.S. Census Bureau
}

\begin{abstract}
CES 13-43 August, 2013
The research program of the Center for Economic Studies (CES) produces a wide range of economic analyses to improve the statistical programs of the U.S. Census Bureau. Many of these analyses take the form of CES research papers. The papers have not undergone the review accorded Census Bureau publications and no endorsement should be inferred. Any opinions and conclusions expressed herein are those of the author(s) and do not necessarily represent the views of the U.S. Census Bureau. All results have been reviewed to ensure that no confidential information is disclosed. Republication in whole or part must be cleared with the authors.

To obtain information about the series, see www.census.gov/ces or contact Fariha Kamal, Editor, Discussion Papers, U.S. Census Bureau, Center for Economic Studies 2K132B, 4600 Silver Hill Road, Washington, DC 20233, CES.Papers.List@census.gov.
\end{abstract}




\begin{abstract}
This study uses worker-level employment data from the U.S. Census Bureau to test whether falling home prices affect a worker's propensity to take a job in a different metropolitan area from where he is currently located. Using a sample of workers from the American Community Survey, I employ a within-MSA-time estimation that compares homeowners to renters in their propensities to relocate for jobs according to data from the Longitudinal Employer Household Dynamics database. This strategy allows me to disentangle the influence of house prices from that of other time-varying, location-specific shocks. Estimates show that homeowners who have experienced declines in the nominal value of their home are approximately $20 \%$ less likely to take a new job in a location outside of the metropolitan area that they currently live and work in, relative to an equivalent renter. This evidence is consistent with the hypothesis that housing lockin has contributed to the decreased labor mobility of homeowners during the recent housing bust.
\end{abstract}




\section{Introduction}

The mobility of labor has long been considered a hallmark strength of the U.S. economy, but during the recent recession the fraction of Americans that migrate between states has fallen to levels not seen in half a century ${ }^{1}$. Many researchers and commentators have suggested that a driving force behind this phenomenon is the historic collapse in the housing market, which has left workers unwilling or unable to sell their homes. Indeed, along with the opportunities to change one's job and wage, housing is a key factor in the migration decision. As such, the movement of house prices can affect migration by changing the costs of relocating for current homeowners, in particular through the changes in home equity which can strongly affect many individuals' financial situations.

While several empirical papers have explored the dynamics between house prices and worker mobility, most data sources and surveys do not follow workers after their household moves, thus preventing a direct measurement of geographic mobility. Furthermore, data that do allow researchers to track individuals are not recorded with sufficient scope and frequency to account for other local economic factors that influence out-migration and house prices. In this paper, I will use a unique set of matched employer-employee level data recorded at a quarterly level, which allows me to find individual workers at their jobs across the United States during the period of 2002-2010. With these data, I can identify the inter-metropolitan job mobility of a sample of homeowners and renters from the American Community Survey, and estimate the effect of house price changes on the propensity to migrate.

The key question addressed here is whether falling house prices deter American work-

\footnotetext{
${ }^{1}$ Washington Post, July 30, 2010
} 
ers from relocating to different areas for new jobs, by effectively trapping them in their current locations. The issue has been raised frequently by the media as of late, in light of the U.S. housing bust which left approximately a third of households owing more on their mortgage than their house is worth, (referred to as being in a state of "negative equity"). ${ }^{2}$ With millions of workers being potential victims of the so-called lock-in phenomenon, the consequences for geographic mobility could be dire. In particular, if the crash in housing prices has reduced out-migration from the distressed areas that have been hit hardest by the downturn, it could impede the efficient reallocation of labor and potentially serve to perpetuate the jobless recovery ${ }^{3}$. Outside of unemployment in itself, lock-in may also simply hinder the efficient reallocation of labor across the country, and further prevent economic recovery.

I tackle the empirical question of how movements in house prices affect labor mobility using worker-level micro data that record an individual's employment and earnings with a particular employer on a quarterly basis. These data, from the Longitudinal EmployerHousehold Dynamics (LEHD) program at the U.S. Census Bureau, allow me to track workers across their jobs during the sample period and therefore determine where a worker is employed at a given point in time. By linking this database with homeownership information for individuals who appear in the American Community Survey, along with local house price information from Zillow, I can test how local house price movements affect the out-migration propensities of homeowners relative to renters in the same Metropolitan Statistical Area (MSA) and time period. This type of within-MSA-time analysis will enable me to disentangle the influence of house prices from the impact of

\footnotetext{
${ }^{2}$ Wall St. Journal, Nov 29, 2009

${ }^{3}$ Lawrence Katz, in the New York Times, Jan. 10, 2010
} 
unobserved local economic factors that also affect migration behavior.

It is theoretically ambiguous whether a housing bust should hinder labor migration. In fact, one may even expect to see a resulting increase in mobility, because falling house prices and the resulting negative equity are the driving forces behind home foreclosures (Gerardi, Shapiro, Willen 2008)[21]. The estimated 2.8 million households who defaulted on their mortgages in 2009 represent a group of workers who are potentially more mobile due to the housing collapse. Furthermore, lower prices do not, in themselves, provide a financial disincentive to relocating, since the diminished proceeds from selling ones home are mitigated by the cheaper prices that other homes can be bought for across the country. In fact, lower house prices can lessen some transaction costs of moving, such as those that are based on a percentage of a home's value.

Nevertheless, there are two reasons why researchers have generally hypothesized that labor mobility should fall as a result of declining home prices. First, people who are underwater on their mortgages may avoid relocating if they do not have the liquidity to cover the monetary costs associated with moving and buying a new home, such as down payments, closing costs, and transfer taxes. The housing finance literature has long focused on the role of such financial constraints in the decision to sell one's home, and has shown how changes in house prices and interest rates can have a deterring effect on moving (Quigley 1987; Stein 1995)[15][22].

Secondly, even if such constraints are not binding, homeowners may be unwilling to move if it forces them to realize any kind of capital loss on their homes (Genesove and Mayer, 1997)[5]. This notion of nominal loss aversion stems from the prospect theory literature pioneered by Kahnemann and Tversky (1979), who showed that a utility function that is kinked or discontinuous at a "reference point" can cause individuals to 
react strongly to nominal losses[12]. Thus, if an owner cannot sell their home for at least a certain amount, such as the original purchase price or the value of the outstanding mortgage, they may be particularly unwilling to realize such a loss.

A sizable empirical literature has provided evidence of both liquidity constraints and loss aversion in the housing market. Genesove and Mayer (2001)[6], for example, study data from home-sellers in Boston and find that those with negative equity tend to keep their houses on the market longer in order to hold out for higher selling prices. Ferreira, Gyourko, and Tracy (2008) estimate duration models of home ownership using data from the American Housing Survey, and also conclude that negative equity leads to lock-in, reducing the probability of moving by about 50 percent[7].

While the impact of negative equity on the propensity to move from one's home is fairly well documented, it is important to note that this does not necessarily translate into an identical effect on job mobility. The above-mentioned studies employ house-level data that do not follow an occupant after they move. Consequently, these papers do not directly address geographic mobility. The fraction of workers who are willing to migrate for jobs at any given point in time is relatively small, and it is not known a priori whether this sub-population is more or less susceptible to the lock-in phenomenon than the average homeowner. It could also be the case that in spite of lock-in, workers who are presented with a job opportunity in another location will find a way to manage without selling their house, by perhaps renting their home or even taking on a long-distance commute or tele-commute to their new job. That is why, in my empirical specification, I model the probability of a worker moving to a new job in a different location-not simply leaving their home-and estimate how house price movements affect this propensity. Only in this way can we determine whether the lock-in effect has a significant effect on job 
mobility and the economy-wide flow of labor.

Few previous studies have used individual-level data that allowed the authors to determine where a homeowner has moved to. Chan (2001) studies homeowners in New York City, and concludes that those who faced financial constraints due to low home equity were 25-33 percent less likely to move out of the city[2]. On the other hand, Engelhardt (2003) is unable to detect much evidence of reduced home equity constraining the inter-metropolitan mobility of young homeowners in the National Longitudinal Survey of Youth between 1985-1996[4]. Note that both of these studies occurred well before the recent recession and the historic collapse of home prices.

More recent literature has begun to cast doubt on the magnitude of the lock-in effect and it's impact on labor mobility. Schulhofer-Wohl (2010) rebuts FGT (2008) saying their results are biased against observing underwater homeowners moving[16]. Farber (2011) says mobility of CPS and Displaced Worker Survey respondents doesn't differ significantly for owners and renters but again mobility is measured by leaving the survey rather than a positive detection of migration[17]. Studies using cross-state analyses show little correlation between declines in state level house prices and the migration rates of homeowners: Aaronson and Davis (2011) uses the SIPP, Schmitt and Warner (2011) uses the DWS, and Dennnet \& Modestino (2012) use IRS data to measure out-migration[19] [20] [18]. The main limitation of these studies is that they don't control for differences in local labor markets, which may bias cross-state analyses if house price movements are correlated with other local economic factors.

Using LEHD data to measure migration of ACS respondents allows me to build on previous literature. Since LEHD data allow me to identify work location, I can directly observe geographic mobility, unlike in many studies. Additionally, the measurement of 
moves is on the basis of jobs, not simply households, increasing the precision of job move measurements and making it of specific relevance to labor market. Perhaps most importantly, however, combining LEHD to measure mobility in the ACS allows me to exploit the large size of the survey, giving me sufficient variation to conduct within-MSA analyses, enabling me to compare owners and renters in the same city at the same time and thus control for local labor market conditions. The size and scope of the sample also gives me greater geographic, demographic, and temporal coverage than most previous studies.

\section{Data Sources}

The sample used in this study comes from the American Community Survey, the largest regular survey of the American population conducted by the Census Bureau. In my analysis I use all ACS respondents and spouses who are either homeowners or renters in one of the 350 Metropolitan Statistical Areas. The survey also provides data on how long the respondent has been living in their current residence. Since I am interested only in the effects of lock-in on labor mobility, I restrict the sample to those aged 18-65 who are actively participating in the civilian labor force (either employed or unemployed). The sample period is from 2002-2010, and the monthly data will be aggregated to the quarterly level for analysis. The size of the ACS from 2002-2004 was about a quarter of its usual size due to the survey being in beta mode at that time, however the within-time nature of the analysis eliminates any bias from this feature. After an ACS household is surveyed it is not surveyed again, so until now there is has been little opportunity to determine anything about the workers in subsequent time periods. 
It is for this purpose that I use the LEHD employment and earnings database, a collection of Unemployment Insurance (UI) records from 49 participating states which goes into producing the Quarterly Workforce Indicators (QWI). UI-covered employment represents over $90 \%$ of all wage and salary civilian jobs. Groups of workers who are not covered by the database include federal employees and the self-employed. Workers in Massachusetts and the District of Columbia are also not currently included. The raw UI data are at the worker-employer (i.e. "job") level, and record the earnings that each worker receives from their employer during a particular quarter. With these data I can observe an ACS individual via internal Census identifiers to all of their LEHDcovered jobs during the sample period 2002-2010. The crucial information about the geographic location of a worker's job comes from the Quarterly Census of Employment and Wage (ES202), which is used to link each of the UI earnings records to a particular work establishment via LEHD algorithms. Specifically, the location of a worker's job is determined by the location of his work establishment on the "Employer Characteristics File" in the LEHD infrastructure.

The data on home values comes from estimates from Zillow.com, a real estate data and analysis firm. Their proprietary algorithm estimates the value of each home, and they publish the monthly median home value by zip-code. This can be linked to the home location of the ACS respondents by linking to the tract of residence. By combining this with ACS information on how long the individual workers have been living in their current residence, this enables a calculation of changes in house prices that are relevant to each worker's own experience in their home. This is important because a fall in house prices will affect an owner who bought their house recently differently than one who bought long ago, since the long-term owners have past years of appreciation to buffer 
them from recent losses. Additionally, the purchase price at the time the owner moved into the home serves as the "reference price" in the context of decisions affected by nominal loss aversion.

\section{Defining Worker Out-Migration}

The hypothetical way in which lock-in can affect job migration is by preventing a current homeowner from taking a job located in an area that is far away from their residence, because to do so would likely require changing residences. Therefore, in order to study such out-migration, we must first define an appropriate concept of geography on which to base our analysis. A natural candidate for such a task is the Office of Management and Budget's concept of a Metropolitan Statistical Area, defined as a region with at least one urban core of 50,000 or more in population, plus adjacent areas that are economically integrated with the core as measured by commuting ties ${ }^{4}$. This makes the MSA well suited for studying the interaction of housing markets and the out-migration of labor, since the MSA is roughly defined as the area in which the workforce also resides. Consequently, a worker who considers taking a new job outside of the MSA must also consider the likely necessary change in residence, making this precisely the sort of job decision that is vulnerable to the influence of housing lock-in.

Thus, the outcome variable of interest is based on the concept of an out-migrator, a worker who leaves a particular metropolitan area to take a job in another location. The theory of lock-in predicts that a homeowner who has experienced house price depreciation will be less likely to transition to a new job in another area, because they will be less

${ }^{4}$ OMB publication 10-02, November 2009 
willing or able to make the necessary change in residence than they would be otherwise. As mentioned above, the MSA is an appropriate concept on which to base measurements of such out-migration, because MSAs are constructed to represent the typical area of residence for workers at a particular employment node. Thus, I define an out-migrator (or job-mover), $m_{i j t}=1$, when the following two conditions are satisfied:

1. ACS worker $i$ is observed in the ACS in MSA $j$ during quarter $t$, but according to the LEHD database is not working in MSA $j$ in quarter $t+1$. This is determined by person $i$ 's MSA $j$ of work and residence in the ACS during the interview quarter t. (I do not require confirmation that worker $i$ is observed in an LEHD job in MSA $j$ during $t$ is required) While the absence of a LEHD job in quarter $t+1$ does not rule out the possibility that the worker is still located in MSA $j$ in time $t+1$, it is at least a minimum requirement for the possibility of a move existing.

2. Worker $i$ begins a new employment spell in the LEHD database at an employer establishment that is located in an MSA other than MSA $j$, beginning within one quarter of the reference ACS time period, i.e. either $t$ or $t+1$. Employment in an adjacent MSA that is considered to be connected by commuting ties, called a Combined Statistical Area (CSA), is not considered to be a move. Likewise, a new job located in a rural area of the same state is not considered to be a move either. The 1 quarter threshold condition is meant to exclude cases where long periods of time have gone unaccounted for and therefore may not represent a clean transition from one job to another. Increasing the threshold can be used in alternate specifications, however.

With this definition of out-migration in hand, we can calculate the national aggregate 
inter-MSA outmigration rate by summing $m$ over all workers in quarter $t$, we define:

$$
\text { mrate }_{j t}=100 *\left(\sum_{j t} m_{i j t}\right) / n_{j t}
$$

where $n_{j t}$ is the total number of ACS workers in the sample.

Thus, mrate $_{i j t}$ expresses the propensity of the current metropolitan workforce to transition to a new job that is not located in the worker's current MSA. Figure 1 displays the time-series of the migration statistics with various thresholds during the sample period 2002q1-2010q3, by Census region. The graphs shows that the out-migration rate gradually declined throughout the decade, a feature of the data that has previously been noted in studies using other measures of interstate migration rates. The quarterly MSAlevel out-migration rate stood at roughly $2 \%$ in the early part of the decade but had declined to around 1\% by 2010:Q3. Also apparent is that the decline accelerated in the years corresponding with the declines in house prices, and stabilizing by the middle of 2009. Migration rates using the 2 and 4 quarter thresholds reveal similar patterns. Regional variation exists as, however, with the South and West regions experiencing the highest rates during the early part of the decade, as well as the largest declines after the housing prices began to collapse. Determining how much of this decline in migration is due to the decline of the housing market rather than to general labor market conditions is the principal goal of this study, and the task for which we turn to within-MSA-time regressions on individual-level data. 


\section{Worker-Level, Within-MSA-time Estimation}

The aim of the key regressions in this study is to determine the effect of house prices changes on the relative out-migration propensity of homeowners, using the concept of outmigration just defined. To properly account for the many possible confounding factors that vary at the MSA-time level, the estimation strategy uses the individual-level data that vary along the dimensions of location, time and ownership status. This strategy allows me to conduct a within-geography an time analysis that controls for MSA-specific time shocks by comparing homeowners to renters in the same MSA and time period. Since changes in house prices should have no direct financial or psychological impact on the migration decision of those who are currently renting, the differential impact of house price changes on owners relative to renters will be representative of the direct effect on owners. The unobserved labor market factors that may be correlated with house prices affect both groups equally, and therefore will be partialed out with the inclusion of MSA-time level interaction dummies. Additionally, changes in the relative costs of housing between the MSA and the rest of the country will be the same for renters and buyers, and will also be differenced out by these MSA-time controls. The individual-level specification has the benefit of modelling the moving decision directly, and thus will give us an estimate of how much a given decline in house prices will affect a homeowner's probability of out-migrating, above and beyond the effect on a renter. This will reflect the direct impact of an owner's change in home equity on their migration decision. Specifically, the regression equation takes the general form: 
$P\left(m_{i j t}=1\right)=\beta_{1}^{\prime}$HousePrices$_{i j t} *$ Own $_{i j t}+\beta_{2}^{\prime}$ Own $_{i j t}+\beta_{3}^{\prime}$ HousePrices $_{i j t}+\gamma_{j t}+$ OtherControls $+\varepsilon_{i j t}$

where HousePrices ${ }_{i j t}$ is one of two variables expressing the change in house prices. The slate of dummy variables, $\gamma_{j t}$ ensures that identification is solely off of within-MSA and time variation.

The dependent variable is the individual probability of out-migrating, $P\left(m_{i j t}\right)$, where $m$ is a $\{0,1\}$ dummy indicating whether worker $i$ switches to a job in a location other than his current MSA of residence $j$ in this quarter $t$, according to the criteria stated in the section above. The threshold used to define migration will typically be 1 quarter in most specifications, but the 2- and 4-quarter thresholds will also be used for robustness.

The key explanatory variable in the analysis is an interaction term between the individual's change in house prices and an indicator of whether a person is living in an owner-occupied home or not. First, let $O w n_{i j t}=1$ if individual $i$ lives in an owneroccupied house in MSA $j$ in time $t$, and 0 if they live in a rented home according to the ACS. Homeownership rates by Census region are shown in Figure 5. The graph shows that homeownership has been declining since the peak of the housing bubble, and especially since the foreclosure crisis of 2009.

Next, the variables representing the change in house prices are based on the change in prices that the person has experienced since moving into their home, which proxies for the gain or loss in home equity that the worker has experienced. Letting $t^{0}$ be the first quarter that the individual lived at the current address, I can calculate the individual- 
specific percentage change in house price change as:

$$
\Delta \ln \left(H P I_{i j t}\right)=\ln \left(H P I_{j t}\right)-\ln \left(H P I_{j t^{0}}\right)
$$

In turn, we can also define:

$$
n_{-} e q u i t y_{i j t}=1 \text { if } \Delta \ln \left(H P I_{i j t}\right)<0 \text {, otherwise } 0
$$

which expresses whether an owner has experienced a home price decline, and can be interpreted as a rough proxy for the presence negative equity. While house price declines are a necessary condition for negative equity, this estimate of negative equity status is of course inexact since we have no information on initial levels of home equity. Figures 2 shows the "negative equity" rate for the entire sample of owners and renters, signifying the percent of the population that has experienced a decline in the value of their home during their tenure. This rate began at virtually 0 in the early years of the sample, and began to increase in late 2006 until the end of the sample where it reached around $50 \%$. Figures 3 and 4 show the distribution of the individual home price changes both before and after the national peak of the housing market in the summer of 2006. There is significant variation in this variable, and the distribution clearly shifts to the left post-peak.

Given these two measures of house price changes, the crucial interaction term is denoted as $H P_{i j t} * O w n_{i j t}$, where HP equals either $\Delta \ln \left(H P I_{i j t}\right)$ or $n_{-} e q u i t y_{i j t}$ depending on the specification. The coefficient on this variable can be interpreted as the effect of house prices on the out-migration decision on homeowners, over and above the effect on 
renters.

A variety of controls are used to ensure identification. First a slate of city-time level dummies, $\gamma_{j t}$ will control for MSA-specific, time-variant shocks such as the local labor market conditions that affect buyers and renters equally. Two more sets of dummies, $O w n * \gamma_{j}$ and $O w n * \gamma_{t}$ will control for the average migration propensities of homeowners by city or by time, respectively. These, in combination with the level dummies, $\gamma_{j}$ and $\gamma_{t}$, account for the fact that migration propensities will differ by either time, location, or ownership status, and some combinations between them. (Note that since there are three levels of variation-time, city, and ownership status, we can include the 3 pairwise interaction terms). Finally, I will include some individual specific $X_{i t}$ variables, such as annual wage, age, sex, race, education, marital status and presence of children.

Identification rests on the assumption that the homeownership decision is exogenous to unobserved factors that might be correlated with both house prices and migration propensities. Buyers and renters clearly are quite different, therefore their migration propensities will likely be quite different. However, the previously described dummy variables control for the different mean migration propensities between the two groups, and these mean differences are even allowed to vary by MSA as well as by time nationally. Identification will only be threatened if there are unobserved factors that affect the changes in the migration propensity of owners vs. renters in a way that is correlated with changes in house prices. For instance, if house prices changes are correlated with something that has heterogeneous effects on people with different characteristics, and these characteristics are strong determinants of homeownership status, it could lead us to incorrectly conclude that the migration of owners is being directly impacted by house price changes. Absent such confounding factors, however, if the respective out- 
migration rates of homeowners and renters react differently to house price movements, (after accounting for various observable differences in propensities), it is likely due to the direct effect of prices on owners.

Given the above definitions of all the variables, we can now write the complete regression specification:

$$
\begin{array}{r}
P\left(m_{i j t}=1\right)=\alpha+\beta_{1}^{\prime} n_{-} e q u i t y_{i j t} * O w n_{i j t}+\beta_{2}^{\prime} O w n_{i j t}+\beta_{3}^{\prime} n_{-} e q u i t y_{i j t} \\
+\beta_{3}^{\prime} O w n_{i j t} * \gamma_{j}+\beta_{4}^{\prime} O w n_{i j t} * \gamma_{t}+\theta^{\prime} X_{i t} \\
+\gamma_{j t}+\gamma_{j}+\gamma_{t}+\varepsilon_{i j t}
\end{array}
$$

where $\beta_{1}$ is the coefficient that expresses the magnitude of this differential, since it represents the interaction effect between homeownership and the proxy for whether a worker has experienced declines in home prices during their tenure. A negative $\beta_{3}$ would indicate that the outmigration of owners is more negatively correlated with the negative equity proxy than the outmigration of renters, supporting the hypothesis that changes in home equity decrease the the ability of homeowners to out-migrate.

In alternate specifications, we will use an independent variable expressing the total percent change in home price instead of the negative equity dummy. The resulting equation is thus:

$$
\begin{array}{r}
P\left(m_{i j t}=1\right)=\alpha+\beta_{1}^{\prime} \Delta \ln \left(H P I_{i j t}\right) * O w n_{i j t}+\beta_{2}^{\prime} O w n_{i j t}+\beta_{3}^{\prime} \Delta \ln \left(H P I_{i j t}\right) \\
+\beta_{3}^{\prime} O w n_{i j t} * \gamma_{j}+\beta_{4}^{\prime} O w n_{i j t} * \gamma_{t}+\theta^{\prime} X_{i t} \\
+\gamma_{j t}+\gamma_{j}+\gamma_{t}+\varepsilon_{i j t}
\end{array}
$$


In this case, $\beta_{1}$ still is the coefficient that expresses the magnitude of the differential impact of house price changes on the migration propensities of owners vs. renters. Here $\beta_{1}>0$ means that the outmigration of owners is more positively correlated with house price changes relative to renters, indicating the direct impact of changes in home equity on owners In other words, it is a positive effect on the key interaction variable that is supportive of the lock-in hypothesis.

While probit is a natural candidate for this sort of estimation, I focus on a baseline linear probability model $(\mathrm{LPM})$ to specify $P\left(m_{i j t}=1\right)$ since it is straightforward to estimate the marginal determinants of migration. Certain probit specifications will also be estimated for robustness. While index models like probit and logit are advantageous in that they restrict the support of the probability space to the unit interval, they also introduce problems which can potentially lead to biased estimates of the marginal effects. LPM is particularly advantageous when the independent variables are discrete, as is the case in the specifications using the negative equity proxy ${ }^{5}$.

\section{$5 \quad$ Results}

\subsection{Baseline results with all labor force participants}

The first test will use all workers in the labor force to test for the lock-in phenomenon. The goal of this first specification is to estimate whether a proxy for whether a worker has experienced a decline in home value during their tenure will decrease a homeowner's probability of taking a new job in another location, compared to that of a renter. For

\footnotetext{
${ }^{5}$ Wooldridge, 2002
} 
these baseline regressions, the entire sample of workers who are reported by ACS as being in the labor force is used.

Standard errors in this specification, and all following specifications, will be clustered by MSA to control for the broad range of error dependencies that can occur between individuals from the same city. Each regression is also weighted by the inverse of the ACS measure of "person weight", which expresses the probability that a given individual is sampled.

Results from the specification using the negative equity proxy instead of the change in prices is shown in Table 2. The coefficients of -.00396 in column 1 and -.00343 reflect the differential impact of negative equity, without and with individual controls, and are both highly statistically significant. The magnitudes express that a nominal house price decline is associated with about a .35 percentage point drop in the outmigration rate of owners vs renters, compared to an average migration rate of 1.6 percent. Thus, this implies that a homeowner who has experienced a decline in their home value is about $20 \%$ less likely to be observed taking a job in a new location than an equivalent renter. Adding individual characteristics in column 2 does not change the results significantly, and the coefficients on the added variables also appear to conform with certain priors: Employed workers, females, married people, people with children in the household, and older workers are all significantly less likely to outmigrate on average.

Table 3 shows the results from the specification using the percent change in house prices as the independent variable. The coefficient on the interaction term between home ownership and house prices of .00594 in column 2 is indeed positive and significant at the 1-percent level, also consistent with the lock-in hypothesis. This means that the migration propensity of owners is more sensitive to house prices than that of renters (an 
increase in prices will increase the relative mobility of owners, and vice versa). Specifically, again using the baseline outmigration rate of $1.6 \%$, the coefficient of about .006 implies that a $20 \%$ change in the value of one's home corresponds to approximately a $7.5 \%$ change in the individual's outmigration propensity, in the opposite direction.

The following tables show results from alternate specifications of the baseline tests. Table 4 shows results using a 2-quarter threshold for detecting migration, as opposed to 1 quarter. The coefficient of approximately .5 in column 1, compared to the unconditional mean of $2.5 \%$, again implies an impact on migration of about $20 \%$ for homeowners who have lost value on their home. Similarly, Table 5 shows the results from using a 4quarter threshold for the migration variable, and the coefficient on the negative equity proxy in column 1 shows an impact of about one percentage point against a baseline of 4 percentage points-again equalling a roughly 25 percent drop in outmigration propensity.

To address possible concerns about the differing a priori probability of observing someone in the LEHD data, I next run the analysis on on subsamples of individuals that we can confirm as having a job in the reference time and MSA of their ACS response. Previous research has shown that survey data does not always correspond to the administrative data used in the LEHD system, and the reasons for such discrepancies are unclear. In Table 6, I report results from a subsample that included only observations where an individual is observed with a job in the reference time $t$ and location $j$ as reported by ACS, and from another one where ACS workers have no corresponding job in the LEHD database. The "confirmed" cases can be thought of as being clean transitions in the LEHD universe, where a worker is observed switching from a job in one MSA $j$ to a new job in another MSA $-j$. Both specifications using the different house price measures show little difference between the confirmed and unconfirmed sample. Furthermore, the 
unconditional out-migration rate for the to groups is about 1.7 for confirmed cases vs 1.5 for confirmed cases. These results verify that there is not an appreciable difference between the two groups. As such, for all the remaining regressions, I will proceed by using the entire sample of confirmed and unconfirmed workers together.

To explore the robustness of the result to a different functional form, I next calculate estimates with a Probit model of the baseline specification. The results, without the inclusion of demographic controls, are shown in Table 7. The coefficient on the interaction variable is negative and significant at the 1 percent level in the n_equity proxy specification, and positive and significant at the 1 percent level in the $\Delta \ln (H P I)$ specification. These results agree with the results from the LPM model, and also support the lock-in hypothesis.

\subsection{Effect on the Unemployed}

While the the lock-in effect may prevent all workers in the labor force from making an beneficial job relocation, it may have an even more deleterious effect on the unemployed, since their labor is potentially being completely wasted due to their inability to move. Researchers have expressed worries that lock-in can strongly affect distressed areas that have experiences declines in both the housing and the labor markets, contributing to unemployment persistence and a slower economic recovery. Such concerns are supported by features of the data such as the one depicted in Figure 6, which shows that the unemployment rate of owners relative to renters has increased dramatically during the Great Recession and housing collapse.

To get at this question of whether lock-in effects the mobility of the unemployed 
in particular, I repeat the within-MSA-time test exclusively on the subset of people that the ACS reports as being unemployed, which can be compared to results from the subsample of employed workers. Employment status is assigned to those whom ACS reports as not having a job, but being available for and actively seeking work. Thus, letting $u_{i j t}=1$ if the ACS defines the person to be unemployed in MSA $j$ and quarter $t$, and 0 otherwise, we can repeat the above analysis on the two subsamples.

Results in Table 8 show mixed support for the lock-in phenomenon affecting the labor mobility of the unemployed. Column 2 shows that the negative equity proxy does not disproportionately affect the out-migration rate of homeowners in a statistically significant way, although the point estimate is still negative. The lack of significance may perhaps be attributable to the fact that the subsample of unemployed is a fairly small fraction of the population, which is further exacerbated by the fact that the negative equity proxy is is a discrete variable that is also of relatively low frequency. By contrast, in the change in house price specification shown in column 4 , the coefficient of .00874 is strongly significant and of the greater magnitude than in the results for the sample of the employed shown in column 3. Note that the continuous variation in the change in house price variable is much greater than the discrete negative equity proxy, perhaps enabling greater precision.

\subsection{Subsample Analysis}

The preceding tests reveal that the migration propensity of homeowners relative to renters appears to be driven by their changes in home equity. The chief threat to this identification, however, is that house prices may be proxying for something that has het- 
erogeneous effects on the owner and renter groups. In particular, we may be worried that such unobserved factors will differentially influence people with different demographic characteristics. Given the very different compositions of the owner and renter pools, such an unobserved influence may be driving the different sensitivities to house prices of the two groups. Although, it should be noted that differences in their mean migration propensities by MSA across time, as well as by time period across the nation, are already accounted for with our controls. In order to address these concerns, we can estimate the regression model on different subsamples and thus include a full interaction between our homeownership and house price variables with certain demographic traits that may capture this heterogeneity. If the results remain fairly consistent across subsamples, we can be more reassured that heterogeneous effects aren't driving the results.

Table 9 estimates the model for males and females separately. (Note that in this, and all of the subsample regressions, only specifications including all the individual level controls will be reported). The signs and magnitudes of the explanatory variable of interest are similar to the baseline results, although the relative sensitivity to house prices appears to be somewhat higher for males. Estimates by race are shown in Table 10, and reveal similar magnitudes of the point estimates, although the negative equity specification is not significant for the nonwhite category in column 2. Table 11 breaks the sample into 3 age categories, 21-25, 36-50, and 51-65. Again all 6 regressions yield coefficients on the interaction term with signs that are consistent with baseline results and consistent with the lock-in hypothesis, although only 3 of them are significant at the $5 \%$ level. Similarly, the results by earnings quartile shown in Table 12 are also consistently similar to the baseline results, although less statistically significant - perhaps due to the smaller number of observations in each of the 4 sub-categories. Table 13 shows 
the results by marital status. Results remain similar to baseline results, although the negative equity specification for unmarried people is insignificant. Also, the magnitude of the sensitivity to house prices is greater for married people. Table 14 shows coefficients that are also consistent with baseline resutlts, although the $n_{-} e q u i t y$ specification is insignificant for workers with children in the house, and generally appears to be stronger for those without children. Finally, Table 15 divides the sample up by the educational attainment. Results are generally of less statistical significance, although every point estimate is of the same sign and general magnitude as before. In fact, in all the previous subsamples, the sign of the coefficient of interest has been consistently of the same sign as, and similar magnitude to the baseline estimates of -.0035 for the negative equity specifications and .006 in the change in prices specifications. In sum, these results show

no reason to be concerned that there are heterogeneous effects on particular demographic groups that may be confounding the baseline estimates.

\section{Conclusion}

This paper has employed a novel method of measuring the impact of house price changes on the outmigration of homeowners, by comparing the effects on owners and renters in the same location and time period. Results from the within-MSA-time analysis reveal that the sensitivity of the migration propensity of homeowners is strongly affected by changes in house prices. Specifically, when an individual homeowner has experienced a decline in the value of his home since moving in, he is approximately $20-25 \%$ less likely to take a new job located in an area outside of his current MSA. Total percent changes in house prices also appear to significantly affect migration propensity-specifically, for 
every $20 \%$ change in house prices, there is an approximate $7.5 \%$ change in out-migration propensity in the opposite direction.

The effect is somewhat less apparent, however, for the unemployed, which in some ways may be the more important group for studying the lock-in effect. However, this is likely due to the small size of the sample of unemployed, which limits the amount of variation that can be observed within a particular MSA-level time period. Nevertheless, taken as a whole, results show that the effect on national worker flows, and hence the economy-wide reallocation of labor, is significant.

Robustness analysis shows a consistent pattern of negative coefficients on the interaction between homeownership and the negative equity proxy, and positive coefficients on the interaction between homeownership and the change in house prices. This alleviates potential concerns that the above results are due to house prices being correlated with unobservable factors that have heterogeneous effects on the owner and renter groups.

Since the evidence for the presence of the lock-in effect on the unemployed is mixed, further work can be done to find different ways to focus on such workers. One option, for example, would be to concentrate on particularly distressed areas and industries, where the susceptibility of workers to lock-in would be particularly detrimental to economic recovery. Nevertheless, the evidence presented in this study that the overall decline in worker mobility can be partially attributable to the collapse in house prices demonstrates an empirical phenomenon that is not easily observable in other previously studied data sources, and one that should be considered when evaluating the future prospects of labor mobility in this country. 


\section{References}

[1] Cameron, A.C. and P.K. Trivedi. "Microeconometrics: Methods and Applications". Cambridge University Press, 2005.

[2] Chan, S. "Spatial Lock-in: Do Falling House Prices Constrain Residential Mobility". Journal of Urban Economics, 49(3):567-586, 2001.

[3] The Economist. "The Road Not Taken", March 2009.

[4] Engelhardt, G. "Nominal Loss Aversion, Housing Equity Constraints, and Household Mobility". Journal of Urban Economics, 53(1):171-195, 2003.

[5] Genesove, D. and C. Mayer. "Equity and Time to Sale in the Real Estate Market". American Economic Review, vol 87(3), pp 255-269, June 2007.

[6] Genesove, D. and C. Mayer. "Loss-aversion and Seller Behavior: Evidence from the Housing Market". Quarterly Journal of Economics, 116(4):1233-60, 2001.

[7] Ferreira, F., J. Gyourko and J. Tracy. "Housing Busts and Household Mobility". NBER Working Paper 14310, 2008.

[8] The Wall Street Journal. "One in Four Borrowers Is Underwater", November 24, 2009.

[9] The New York Times. "A Nation of Hunkered-Down Homebodies", January 10, 2010.

[10] The Wall Street Journal. "Foreclosures Hit High In 2009, Saw Spike In December" - RealtyTrac, January 14, 2010. 
[11] Hunt, Gary L., and Richard E. Mueller. 2004. North American Migration: Returns to Skill, Border Effects, and Mobility Costs, The Review of Economics and Statistics 86, 988-1007.

[12] Kahnneman, D. and A. Tversky. "Prospect Theory: An Analysis of Decision Under Risk". Econometrica, 47:263-291, 1979.

[13] Kennan, J. and J. R. Walker. "The Effect Income on Individual Migration Decisions," unpublished manuscript, University of Wisconsin-Madison.

[14] McCall, B. "Unemployment Insurance Rules, Joblessness, and Part-Time Work". Econometrica, 64(1):647-682, 1996.

[15] Quigley, J.M. "Interest Rate Variations, Mortgage Prepayments and Household Mobility". Review of Economics and Statistics, 69:636-643, 1987.

[16] Schulhofer-Wohl, S. "Negative Equity does not reduce homeowners' mobility"'. Federal Reserve Bank of Minneapolis Working Paper

[17] Farber, H. "Job Loss in the Great Recession: Historical Perspectives from the Displaced Workers Survey 1984-2010". NBER Working Paper 170402010.

[18] Dennett, J. and A. Modestino. "Are American Homeowners Locked in their Houses: The Impact of Housing Market Conditions on State-to-State Migration". Federal Reserve Bank of Boston Working Paper 12-1. 2011.

[19] Aaronson, D. and J. Davis. "How Much has House Lock Affected Labor Mobility and the Unemployment Rate". Chicago Fed Letter No.290, September 2011. 
[20] Schmitt, J. and C. Warner. "Deconstructing Structural Unemployment". Center for Economic and Policy Research Papers March 24, 2011.

[21] Gerardi, K., A.H. Shapiro and P. Willen. "Subprime Outcomes: Risky Mortgages, Homeownership Experiences, and Foreclosures". Federal Reserve Bank of Boston, Working Paper 07-15, 2008.

[22] Stein, J. "Prices and Trading Volume in the Housing Market: A Model with DownPayment Effects". Quarterly Journal of Economics, 110:379-406, 1995.

\section{A Figures}


Figure 1: Out-Migration Rates by Census Region

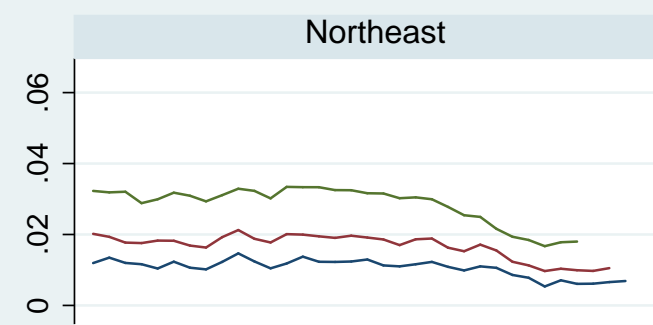

South

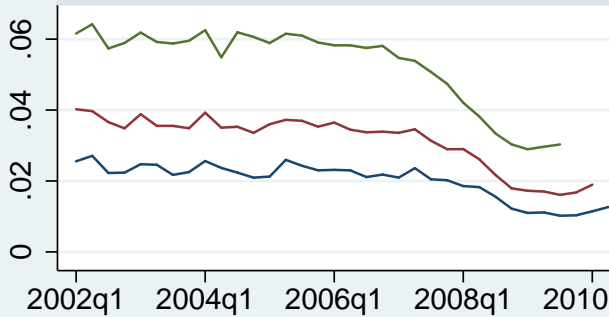

-
Midwest

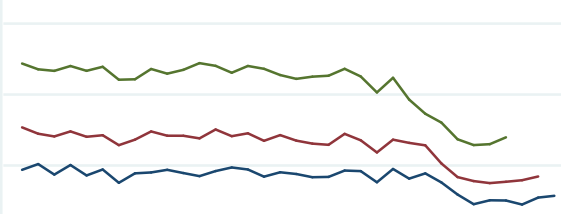

West

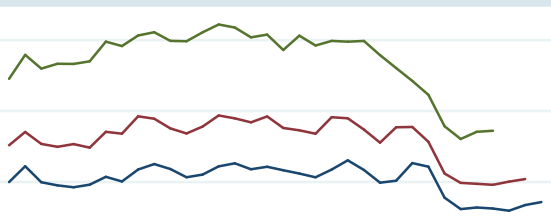

$2004 q 12006 q 1 \quad 2008 q 1 \quad 2010 q 1$ 2-qtr Threshold

1-qtr Threshold 4-qtr Threshold 
Figure 2: Estimated Negative Equity Rate

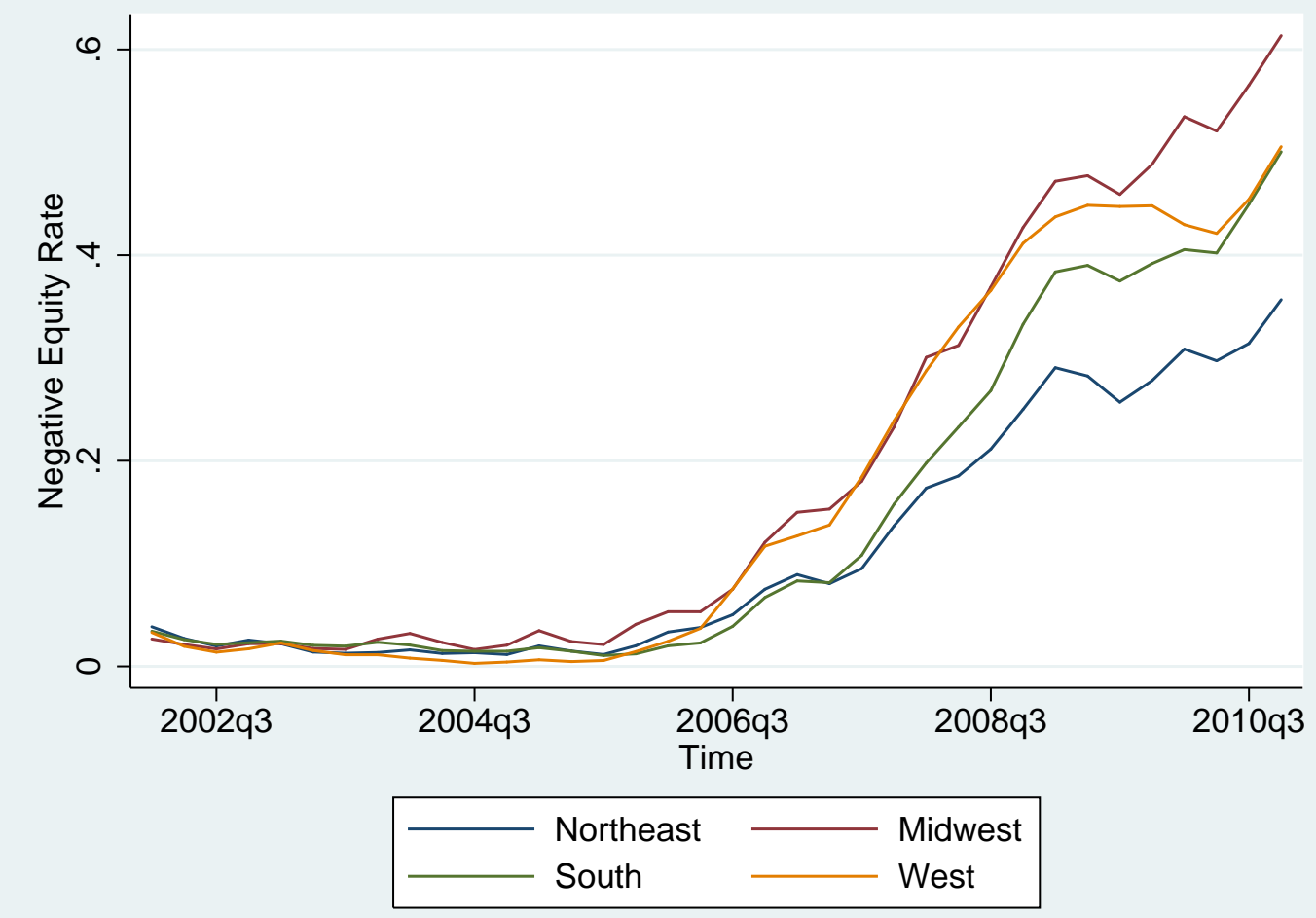


Figure 3: Dist. of Home Price Changes pre-2006q3

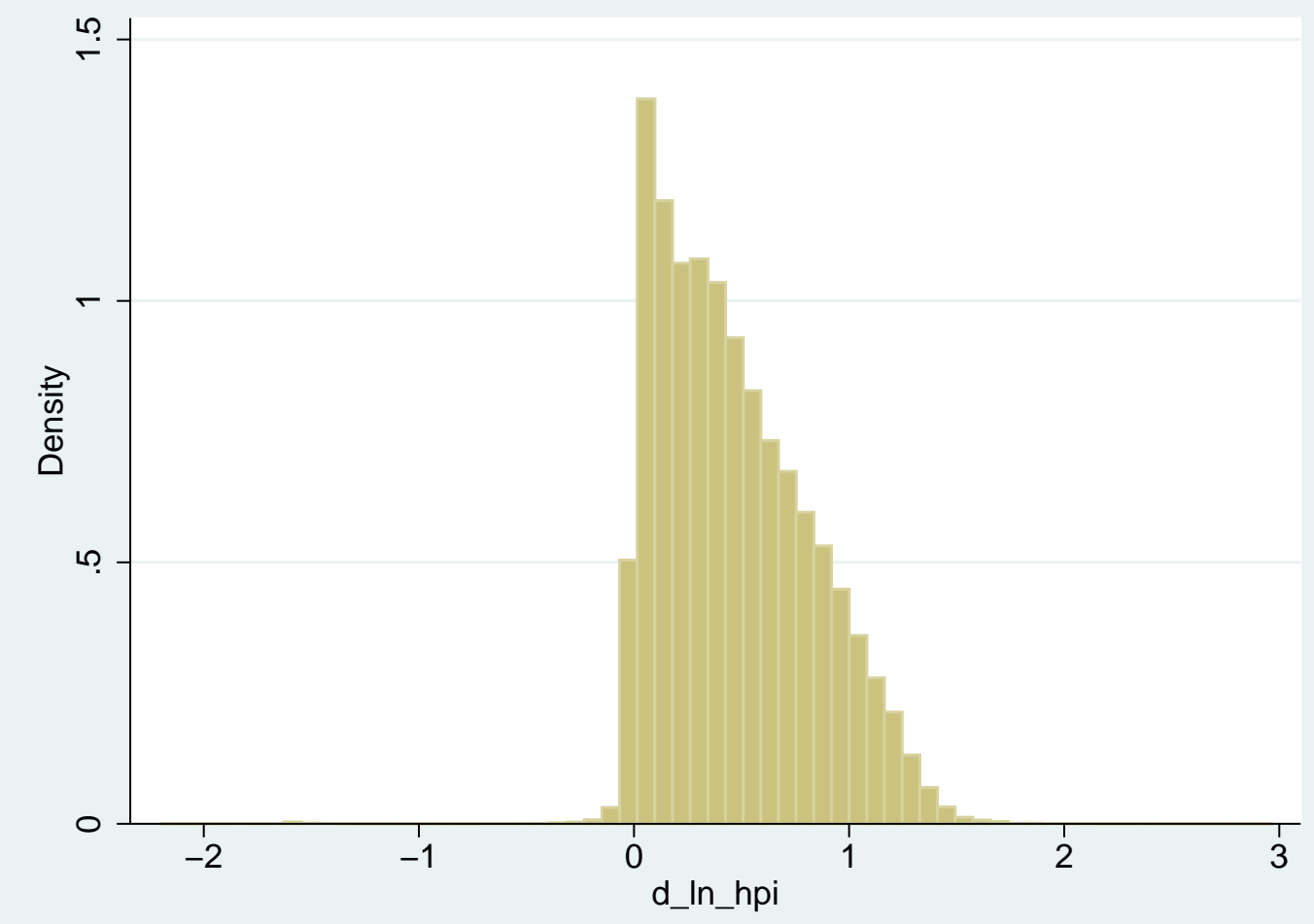


Figure 4: Dist. of Home Price Changes post-2006q3

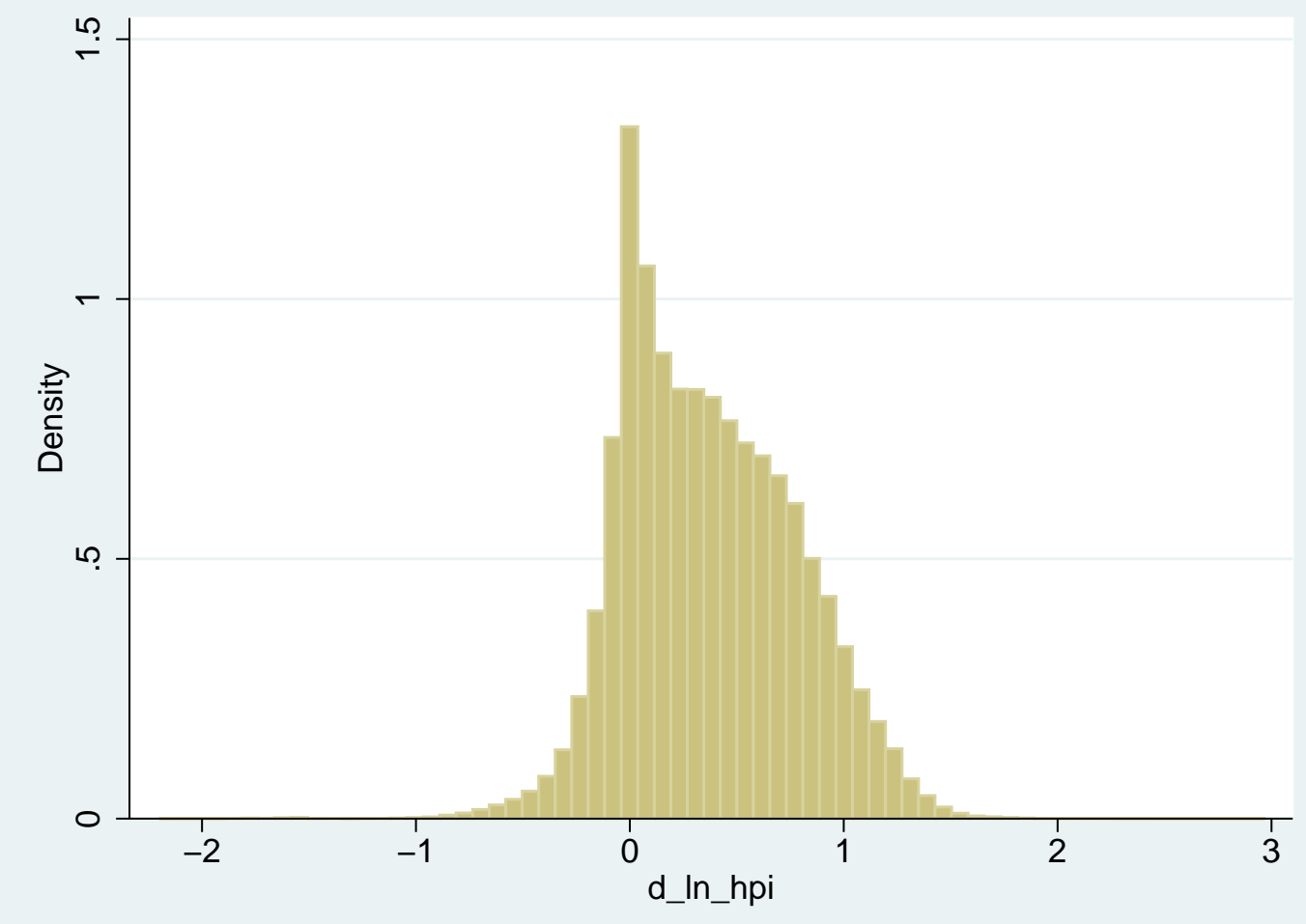


Figure 5: Sample Homeownership Rate by Census Region

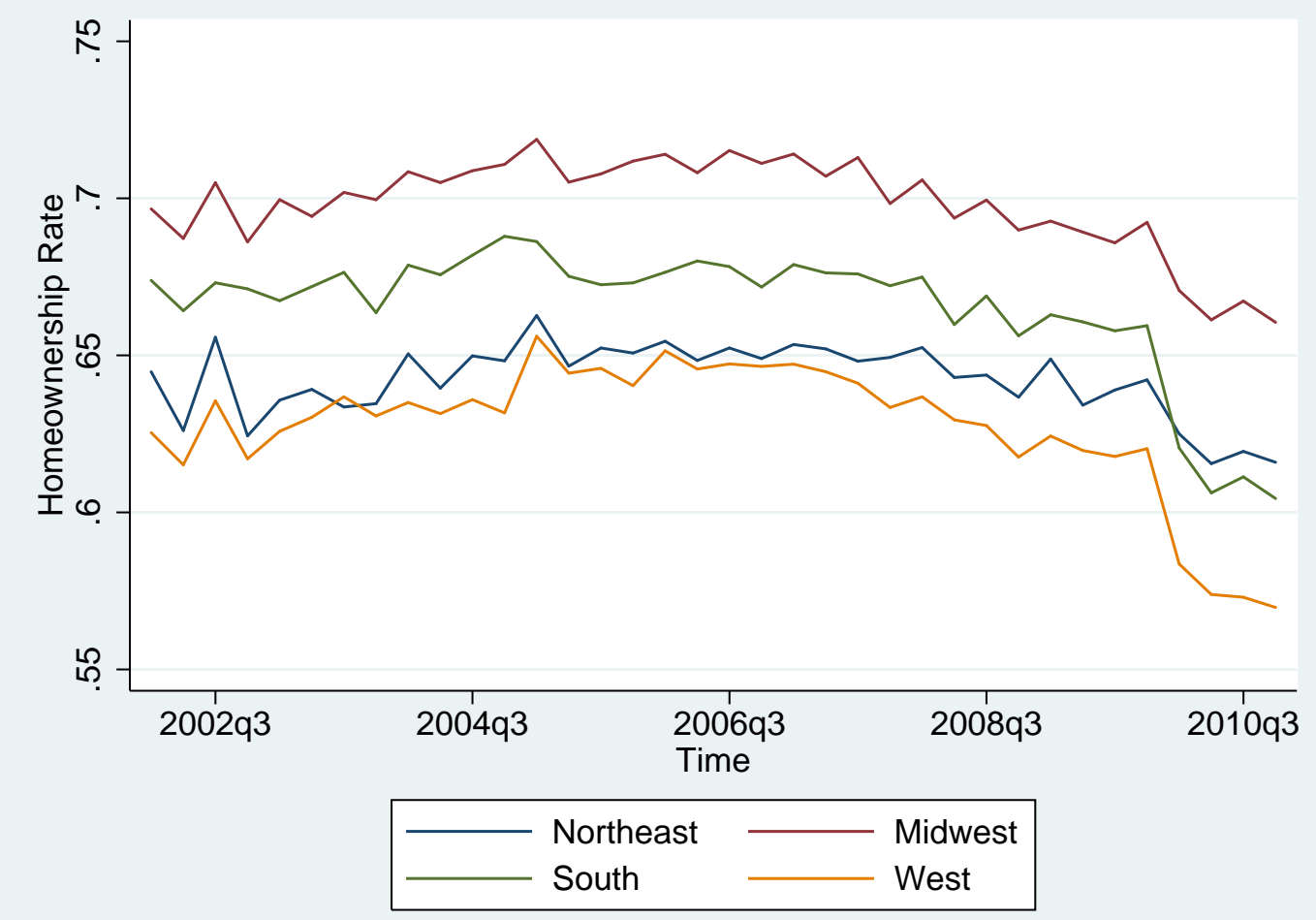


Figure 6: CPS Unemployment by Ownership Status

\section{SA - Unemployment Rate Ratio: Owners/Renters}

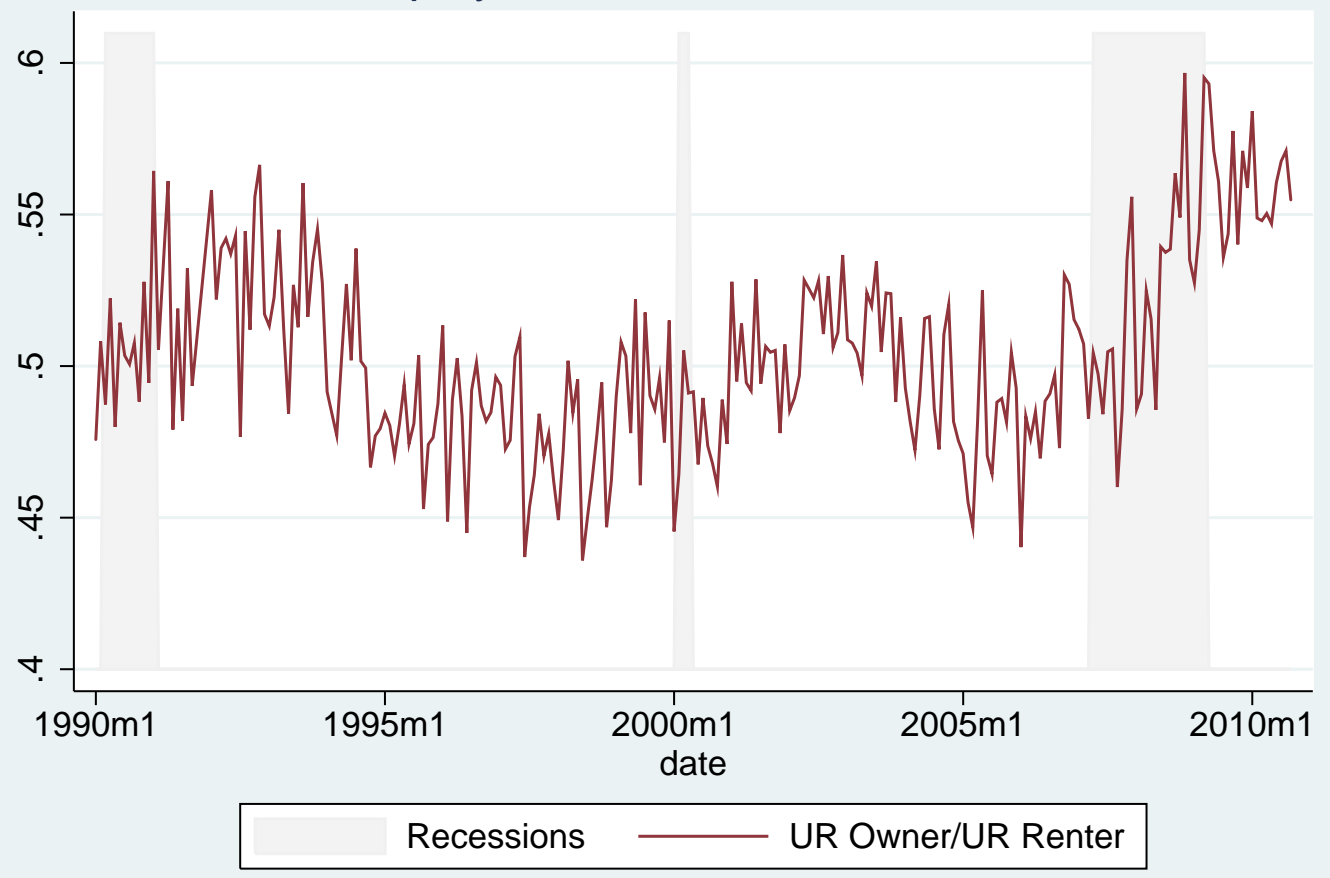


B Tables 
Table 1: Summary Statistics

\begin{tabular}{lcccc}
\hline \hline \multicolumn{1}{c}{ Variable } & Mean & Std. Dev. & Min. & Max. \\
\hline move_1 & 0.016 & 0.126 & 0 & 1 \\
move_2 & 0.025 & 0.156 & 0 & 1 \\
move_4 & 0.04 & 0.196 & 0 & 1 \\
own & 0.658 & 0.474 & 0 & 1 \\
$\Delta l n(H P I)$ & 0.367 & 0.403 & -2.201 & 2.971 \\
n_equity & 0.183 & 0.387 & 0 & 1 \\
age & 44.325 & 10.98 & 18 & 65 \\
female & 0.493 & 0.5 & 0 & 1 \\
nonwhite & 0.198 & 0.399 & 0 & 1 \\
married & 0.715 & 0.451 & 0 & 1 \\
children & 0.449 & 0.497 & 0 & 1 \\
earn/1000 & 49.871 & 61.683 & 0 & 999.999 \\
unemp & 0.075 & 0.263 & 0 & 1 \\
$<$ highschool & 0.066 & 0.249 & 0 & 1 \\
hs_diploma & 0.216 & 0.412 & 0 & 1 \\
some_coll & 0.311 & 0.463 & 0 & 1 \\
college+ & 0.407 & 0.491 & 0 & 1 \\
\hline N $5,973,937$ & & & &
\end{tabular}

$\mathbf{N}=5,973,937$ 
Table 2: All Worker Sample: Negative Equity Dummy

\begin{tabular}{l|c|c}
\hline \hline & $(1)$ & $(2)$ \\
\hline & $\beta /$ s.e. & $\beta /$ s.e. \\
own & $-0.00396^{* * *}$ & $-0.00343^{* * *}$ \\
& $(0.00074)$ & $(0.00067)$ \\
$n \_$_equity & $-0.00476^{*}$ & -0.00157 \\
earn $/ 1000$ & $(0.00173)$ & $(0.00173)$ \\
& $0.00746^{* * *}$ & $0.00393^{* * *}$ \\
unemp & $(0.00093)$ & $(0.00069)$ \\
& & $-0.00000^{*}$ \\
age & & $(0.00000)$ \\
& & $0.01089^{* * *}$ \\
female & & $(0.00112)$ \\
& & $-0.00038^{* * *}$ \\
nonwhite & & $(0.00003)$ \\
married & & $-0.00441^{* * *}$ \\
children & & $(0.00039)$ \\
highschool & & $0.00076^{*}$ \\
& & $(0.00035)$ \\
somecoll & $-0.00226^{* * *}$ \\
& & $(0.00038)$ \\
college+ & & $-0.00155^{* * *}$ \\
& & $(0.00023)$ \\
$* \mathrm{p} \leq 0.05, * * \mathrm{p} \leq 0.01, * * * \mathrm{p} \leq 0.001$ & $-0.00173^{* * *}$ \\
& & $(0.00045)$ \\
& & -0.00099 \\
& & $(0.00049)$ \\
& & -0.00050 \\
& & $(0.00051)$ \\
\hline
\end{tabular}

Notes: Sample consists of 5,973,937 ACS individuals $i$, either household head or spouse age 18-65, and in the labor force, who are observed in one of the 350 MSAs $j$ during a given quarter $t$ in 2002q1-2010q3. All regressions include the following sets of controls: Ownership status X MSA, MSA X time period, Ownership status X time period (results omitted for clarity). The individual characteristic variables, if included, consist of binary indicator variables Female, Nonwhite, Married and Children, as well as continuous variables earn/1000 and age. Education categories, HS, SomeColl, and College+ are all relative to the omitted category of LessthanHS. Standard errors are clustered by MSA to account for general error dependencies within an MSA across time. Coefficient on the ownership*house-price-change variable represents the differential response in outmigration rates to house price changes by owners relative to renters. 
Table 3: All Worker Sample: Change in Prices

\begin{tabular}{|c|c|c|}
\hline & $\overline{(1)}$ & $(2)$ \\
\hline$\Delta \ln (H P I) X o w n_{i j t}$ & $\begin{array}{c}\beta / \text { s.e. } \\
0.00689^{* * *} \\
(0.00170)\end{array}$ & $\begin{array}{c}\beta / \text { s.e. } \\
0.00594^{* * *} \\
(0.00148)\end{array}$ \\
\hline own & $\begin{array}{c}-0.00675^{* * *} \\
(0.00174)\end{array}$ & $\begin{array}{l}-0.00374^{*} \\
(0.00170)\end{array}$ \\
\hline$\Delta \ln (H P I)$ & $\begin{array}{c}-0.01257^{* * *} * \\
(0.00234)\end{array}$ & $\begin{array}{c}-0.00745^{* * *} * \\
(0.00186)\end{array}$ \\
\hline earn/1000 & & $\begin{array}{l}-0.00000^{*} \\
(0.00000)\end{array}$ \\
\hline unemp & & $\begin{array}{c}0.01085^{* * *} \\
(0.00111)\end{array}$ \\
\hline age & & $\begin{array}{c}-0.00034^{* * *} \\
(0.00002)\end{array}$ \\
\hline female & & $\begin{array}{c}-0.00435^{* * *} \\
(0.00039)\end{array}$ \\
\hline nonwhite & & $\begin{array}{l}0.00072^{*} \\
(0.00035)\end{array}$ \\
\hline married & & $\begin{array}{c}-0.00215^{* * *} \\
(0.00037)\end{array}$ \\
\hline children & & $\begin{array}{c}-0.00144^{* * *} * \\
(0.00023)\end{array}$ \\
\hline highschool & & $\begin{array}{c}-0.00179^{* * *} \\
(0.00047)\end{array}$ \\
\hline somecoll & & $\begin{array}{c}-0.00109^{*} \\
(0.00051)\end{array}$ \\
\hline college+ & & $\begin{array}{l}-0.00063 \\
(0.00053)\end{array}$ \\
\hline
\end{tabular}

Notes: Sample consists of 5,973,937 ACS individuals $i$, either household head or spouse age 18-65, and in the labor force, who are observed in one of the 350 MSAs $j$ during a given quarter $t$ in 2002q1-2010q3. All regressions include the following sets of controls: Ownership status X MSA, MSA X time period, Ownership status X time period (results omitted for clarity). The individual characteristic variables, if included, consist of binary indicator variables Female, Nonwhite, Married and Children, as well as continuous variables earn/1000 and age. Education categories, HS, SomeColl, and College+ are all relative to the omitted category of LessthanHS. Standard errors are clustered by MSA to account for general error dependencies within an MSA across time. Coefficient on the ownership*house-price-change variable represents the differential response in outmigration rates to house price changes by owners relative to renters. 
Table 4: All Worker Sample: 2-qtr Migration Thresshold

\begin{tabular}{|c|c|c|c|c|}
\hline House Price Variable $\left(H P_{i j t}\right)$ & $\begin{array}{c}(1) \\
\text { n_equity }\end{array}$ & $\begin{array}{c}(2) \\
\mathbf{n} \_ \text {equity }\end{array}$ & $\begin{array}{c}(3) \\
\Delta \ln (\text { HPI })\end{array}$ & $\begin{array}{c}(4) \\
\Delta \ln (\text { HPI })\end{array}$ \\
\hline Individual Controls Included? & no & yes & no & yes \\
\hline$H P_{i j t} X_{o w n} n_{i j t}$ & $\begin{array}{c}\beta / \text { s.e. } \\
-0.00717^{* * *} \\
(0.00119)\end{array}$ & $\begin{array}{c}\beta / \text { s.e. } \\
-0.00631^{* * *} \\
(0.00104)\end{array}$ & $\begin{array}{c}\beta / \text { s.e. } \\
0.01197^{* * *} \\
(0.00232)\end{array}$ & $\begin{array}{c}\beta / \text { s.e. } \\
0.01042^{* * *} \\
(0.00197)\end{array}$ \\
\hline$o w n_{i j t}$ & $\begin{array}{c}-0.01258^{* * * *} \\
(0.00258)\end{array}$ & $\begin{array}{c}-0.00750^{* *} \\
(0.00253)\end{array}$ & $\begin{array}{c}-0.01610^{* * *} \\
(0.00281)\end{array}$ & $\begin{array}{c}-0.01133 * * * \\
(0.00272)\end{array}$ \\
\hline$H P_{i j t}$ & $\begin{array}{c}0.01232^{* * *} \\
(0.00143)\end{array}$ & $\begin{array}{c}0.00657^{* * *} \\
(0.00104)\end{array}$ & $\begin{array}{c}-0.02084^{* * *} \\
(0.00339)\end{array}$ & $\begin{array}{c}-0.01250^{* * * *} \\
(0.00256)\end{array}$ \\
\hline
\end{tabular}

Notes: Sample consists of 5,973,937 ACS individuals $i$, either household head or spouse age 18-65, and in the labor force, who are observed in one of the 350 MSAs $j$ during a given quarter $t$ in 2002q1-2010q1. All regressions include the following sets of controls: Ownership status X MSA, MSA X time period, Ownership status X time period (results omitted for clarity). The individual characteristic variables, if included, consist of binary indicator variables Female, Nonwhite, Married and Children, as well as continuous variables earn/1000 and age. Education categories, HS, SomeColl, and College+ are all relative to the omitted category of LessthanHS. Standard errors are clustered by MSA to account for general error dependencies within an MSA across time. Coefficient on the ownership*house-price-change variable represents the differential response in outmigration rates to house price changes by owners relative to renters. 
Table 5: All Worker Sample: 4-qtr Migration Threshold

\begin{tabular}{l|c|c|c|c}
\hline \hline & $(1)$ & $(2)$ & $(3)$ & $(4)$ \\
House Price Variable $\left(H P_{i j t}\right)$ & n_equity & n_equity & $\Delta \ln (\mathbf{H P I})$ & $\Delta \ln (\mathbf{H P I})$ \\
\hline Individual Controls Included? & no & yes & no & yes \\
\hline & $\beta /$ s.e. & $\beta /$ s.e. & $\beta /$ s.e. & $\beta /$ s.e. \\
$H P_{i j t} X$ own & & & \\
& $-0.01227^{* * *}$ & $-0.01085^{* * *}$ & $0.02145^{* * *}$ & $0.01888^{* * *}$ \\
own & $(0.00162)$ & $(0.00137)$ & $(0.00380)$ & $(0.00325)$ \\
& $-0.02138^{* * *}$ & $-0.01294^{* * *}$ & $-0.02770^{* * *}$ & $-0.01987^{* * *}$ \\
$H P_{i j t}$ & $(0.00322)$ & $(0.00297)$ & $(0.00388)$ & $(0.00358)$ \\
& $0.02028^{* * *}$ & $0.01050^{* * *}$ & $-0.03627^{* * *}$ & $-0.02221^{* * *}$ \\
${ }^{*} \mathrm{p} \leq 0.05,{ }^{* *} \mathrm{p} \leq 0.01,{ }^{* * *} \mathrm{p} \leq 0.001$ & $(0.00202)$ & $(0.00141)$ & $(0.00551)$ & $(0.00418)$ \\
\hline
\end{tabular}

Notes: Sample consists of 5,973,937 ACS individuals $i$, either household head or spouse age 18-65, and in the labor force, who are observed in one of the 350 MSAs $j$ during a given quarter $t$ in 2002q1-2009q4. All regressions include the following sets of controls: Ownership status X MSA, MSA X time period, Ownership status X time period (results omitted for clarity). The individual characteristic variables, if included, consist of binary indicator variables Female, Nonwhite, Married and Children, as well as continuous variables earn/1000 and age. Education categories, HS, SomeColl, and College+ are all relative to the omitted category of LessthanHS. Standard errors are clustered by MSA to account for general error dependencies within an MSA across time. Coefficient on the ownership*house-price-change variable represents the differential response in outmigration rates to house price changes by owners relative to renters. 
Table 6: Sample by whether reference job is LEHD-confirmed

\begin{tabular}{|c|c|c|c|c|}
\hline $\begin{array}{l}\text { Population } \\
\text { House Price Variable }\left(H P_{i j t}\right)\end{array}$ & $\begin{array}{c}(1) \\
\text { Confirmed } \\
\text { n_equity }\end{array}$ & $\begin{array}{c}(2) \\
\text { Unconfirmed } \\
\text { n_equity }\end{array}$ & $\begin{array}{c}(3) \\
\text { Confirmed } \\
\Delta \ln (\mathrm{HPI}) \\
\end{array}$ & $\begin{array}{c}(4) \\
\text { Unconfirmed } \\
\Delta \ln (\mathrm{HPI})\end{array}$ \\
\hline Individual Controls Included? & yes & yes & yes & yes \\
\hline$H P_{i j t} X_{o w n} n_{i j t}$ & $\begin{array}{c}\beta / \text { s.e. } \\
-0.00322^{* *} \\
(0.00095)\end{array}$ & $\begin{array}{c}\beta / \text { s.e. } \\
-0.00370^{* * *} \\
(0.00076)\end{array}$ & $\begin{array}{c}\beta / \text { s.e. } \\
0.00528^{*} \\
(0.00193)\end{array}$ & $\begin{array}{c}\beta / \text { s.e. } \\
0.00663^{* * *} \\
(0.00127)\end{array}$ \\
\hline$o w n_{i j t}$ & $\begin{array}{c}0.00033 \\
(0.00274)\end{array}$ & $\begin{array}{l}-0.00310 \\
(0.00249)\end{array}$ & $\begin{array}{l}-0.00147 \\
(0.00270)\end{array}$ & $\begin{array}{c}-0.00563^{*} \\
(0.00248)\end{array}$ \\
\hline$H P_{i j t}$ & $\begin{array}{c}0.00430 * * * \\
(0.00096)\end{array}$ & $\begin{array}{c}0.00361^{* * *} \\
(0.00076)\end{array}$ & $\begin{array}{c}-0.00704^{* *} \\
(0.00223)\end{array}$ & $\begin{array}{c}-0.00777^{* * *} \\
(0.00162)\end{array}$ \\
\hline
\end{tabular}

Notes: Sample consists of 5,973,937 ACS individuals $i$, either household head or spouse age 18-65, and in the labor force, who are observed in one of the 350 MSAs $j$ during a given quarter $t$ in 2002q1-2010q3. All regressions include the following sets of controls: Ownership status X MSA, MSA X time period, Ownership status X time period (results omitted for clarity). The individual characteristic variables, if included, consist of binary indicator variables Female, Nonwhite, Married and Children, as well as continuous variables earn/1000 and age. Education categories, HS, SomeColl, and College+ are all relative to the omitted category of LessthanHS. Standard errors are clustered by MSA to account for general error dependencies within an MSA across time. Coefficient on the ownership*house-price-change variable represents the differential response in outmigration rates to house price changes by owners relative to renters. 
Table 7: All Worker Sample: Probit

\begin{tabular}{l|c|c}
\hline \hline & $(1)$ & $(2)$ \\
House Price Variable $\left(H P_{i j t}\right)$ & n_equity & $\Delta \ln (\mathbf{H P I})$ \\
\hline & $\beta / \mathrm{s.e.}$ & $\beta / \mathrm{s.e.}$ \\
$H P_{i j t}$ Xown & & \\
& $-0.04862^{* * *}$ & $0.12351^{* * *}$ \\
own $_{i j t}$ & $(0.01266)$ & $(0.03224)$ \\
& $-0.14344^{* * *}$ & $-0.16652^{* * *}$ \\
$H P_{i j t}$ & $(0.03355)$ & $(0.03234)$ \\
& $-0.17609^{* * *}$ & $-0.30356^{* * *}$ \\
${ }^{*} \mathrm{p} \leq 0.05,{ }^{* *} \mathrm{p} \leq 0.01,{ }^{* * *} \mathrm{p} \leq 0.001$ & $(0.01336)$ & $(0.03821)$ \\
\hline
\end{tabular}

Notes: Sample consists of 5,973,937ACS individuals $i$, either household head or spouse age 18-65, and in the labor force, who are observed in one of the 350 MSAs $j$ during a given quarter $t$ in 2002q1-2010q3. All regressions include the following sets of controls: Ownership status X MSA, MSA X time period, Ownership status X time period (results omitted for clarity). The individual characteristic variables, if included, consist of binary indicator variables Female, Nonwhite, Married and Children, as well as continuous variables earn/1000 and age. Education categories, HS, SomeColl, and College+ are all relative to the omitted category of LessthanHS. Standard errors are clustered by MSA to account for general error dependencies within an MSA across time. Coefficient on the ownership*house-price-change variable represents the differential response in outmigration rates to house price changes by owners relative to renters. 
Table 8: Results by Employment Status

\begin{tabular}{l|c|c|c|c}
\hline \hline Population & $\begin{array}{c}(1) \\
\text { Employed } \\
\text { House Price Variable }\left(H P_{i j t}\right)\end{array}$ & $\begin{array}{c}(2) \\
\text { Unemployed } \\
\mathbf{n}_{\text {nequity }}\end{array}$ & $\begin{array}{c}(3) \\
\text { Employed } \\
\Delta \ln (\mathbf{H P I})\end{array}$ & $\begin{array}{c}(4) \\
\text { Unemployed } \\
\Delta \ln (\mathbf{H P I})\end{array}$ \\
\hline Individual Controls Included? & yes & yes & yes & yes \\
\hline \multirow{3}{*}{$P_{i j t}$ Xown } & $\beta /$ s.e. & $\beta /$ s.e. & $\beta /$ s.e. & $\beta /$ s.e. \\
& $-0.00359^{* * *}$ & -0.00103 & $0.00556^{* * *}$ & $0.00874^{* *}$ \\
own $_{i j t}$ & $(0.00067)$ & $(0.00186)$ & $(0.00140)$ & $(0.00306)$ \\
$H P_{i j t}$ & -0.00155 & -0.00344 & $-0.00361^{*}$ & -0.00631 \\
& $(0.00163)$ & $(0.00770)$ & $(0.00157)$ & $(0.00812)$ \\
& $0.00389^{* * *}$ & $0.00449^{* *}$ & $-0.00695^{* * *}$ & $-0.01228^{* *}$ \\
\hline
\end{tabular}

${ }^{*} \mathrm{p} \leq 0.05,{ }^{* *} \mathrm{p} \leq 0.01,{ }^{* * *} \mathrm{p} \leq 0.001$

Notes: Sample consists of 5,973,937 ACS individuals $i$, either household head or spouse age 18-65, and in the labor force, who are observed in one of the 350 MSAs $j$ during a given quarter $t$ in 2002q1-2010q3. All regressions include the following sets of controls: Ownership status X MSA, MSA X time period, Ownership status X time period (results omitted for clarity). The individual characteristic variables, if included, consist of binary indicator variables Female, Nonwhite, Married and Children, as well as continuous variables earn/1000 and age. Education categories, HS, SomeColl, and College+ are all relative to the omitted category of LessthanHS. Standard errors are clustered by MSA to account for general error dependencies within an MSA across time. Coefficient on the ownership*house-price-change variable represents the differential response in outmigration rates to house price changes by owners relative to renters. 
Table 9: Results by Sex

\begin{tabular}{|c|c|c|c|c|}
\hline $\begin{array}{l}\text { Population } \\
\text { House Price Variable }\left(H P_{i j t}\right)\end{array}$ & $\begin{array}{c}(1) \\
\text { Female } \\
\text { n_equity }\end{array}$ & $\begin{array}{c}(2) \\
\text { Male } \\
\text { n_equity }\end{array}$ & $\begin{array}{c}(3) \\
\text { Female } \\
\Delta \ln (\text { HPI })\end{array}$ & $\begin{array}{c}(4) \\
\text { Male } \\
\Delta \ln (\text { HPI }) \\
\end{array}$ \\
\hline Individual Controls Included? & yes & yes & yes & yes \\
\hline$H P_{i j t}$ Xown $_{i j t}$ & $\begin{array}{c}\beta / \text { s.e. } \\
-0.00306^{* * *} \\
(0.00081)\end{array}$ & $\begin{array}{c}\beta / \text { s.e. } \\
-0.00379^{* * *} \\
(0.00074)\end{array}$ & $\begin{array}{c}\beta / \text { s.e. } \\
0.00536^{* *} \\
(0.00166)\end{array}$ & $\begin{array}{c}\beta / \text { s.e. } \\
0.00654^{* * *} \\
(0.00147)\end{array}$ \\
\hline$o w n_{i j t}$ & $\begin{array}{l}-0.00335 \\
(0.00174)\end{array}$ & $\begin{array}{c}0.00031 \\
(0.00278)\end{array}$ & $\begin{array}{c}-0.00535^{* *} \\
(0.00173)\end{array}$ & $\begin{array}{l}-0.00205 \\
(0.00285)\end{array}$ \\
\hline$H P_{i j t}$ & $\begin{array}{c}0.00366^{* * *} \\
(0.00081)\end{array}$ & $\begin{array}{c}0.00417^{* * *} \\
(0.00073)\end{array}$ & $\begin{array}{c}-0.00654^{* *} \\
(0.00186)\end{array}$ & $\begin{array}{c}-0.00829^{* * *} \\
(0.00192)\end{array}$ \\
\hline
\end{tabular}

Notes: Sample consists of 5,973,937 ACS individuals $i$, either household head or spouse age 18-65, and in the labor force, who are observed in one of the 350 MSAs $j$ during a given quarter $t$ in 2002q1-2010q3. All regressions include the following sets of controls: Ownership status X MSA, MSA X time period, Ownership status X time period (results omitted for clarity). The individual characteristic variables, if included, consist of binary indicator variables Female, Nonwhite, Married and Children, as well as continuous variables earn/1000 and age. Education categories, HS, SomeColl, and College+ are all relative to the omitted category of LessthanHS. Standard errors are clustered by MSA to account for general error dependencies within an MSA across time. Coefficient on the ownership*house-price-change variable represents the differential response in outmigration rates to house price changes by owners relative to renters. 
Table 10: Results by Race

\begin{tabular}{l|c|c|c|c}
\hline \hline Population & $\begin{array}{c}(1) \\
\text { White } \\
\text { House Price Variable }\left(H P_{i j t}\right)\end{array}$ & $\begin{array}{c}(2) \\
\text { Nonwhite } \\
\text { n_equity }\end{array}$ & $\begin{array}{c}(3) \\
\text { White } \\
\text { n_equity }\end{array}$ & $\begin{array}{c}(4) \\
\text { Nonwhite }\end{array}$ \\
\hline Individual Controls Included? & yes & yes & yes & yes \\
\hline & $\beta /$ s.e. & $\beta /$ s.e. & $\beta /$ s.e. & $\beta /$ s.e. \\
$H P_{i j t} X o w n_{i j t}$ & $-0.00422^{* * *}$ & -0.00117 & $0.00671^{* * *}$ & $0.00510^{* * *}$ \\
& $(0.00069)$ & $(0.00109)$ & $(0.00162)$ & $(0.00128)$ \\
own $_{i j t}$ & 0.00003 & -0.00649 & -0.00249 & -0.00825 \\
$H P_{i j t}$ & $(0.00224)$ & $(0.00396)$ & $(0.00205)$ & $(0.00413)$ \\
& $0.00427^{* * *}$ & $0.00302^{* *}$ & $-0.00869^{* * *}$ & $-0.00527^{* *}$ \\
$* \mathrm{p} \leq 0.05, * * \mathrm{p} \leq 0.01, * * * \mathrm{p} \leq 0.001$ & $(0.00072)$ & $(0.00098)$ & $(0.00205)$ & $(0.00158)$ \\
\hline
\end{tabular}

Notes: Sample consists of 5,973,937 ACS individuals $i$, either household head or spouse age 18-65, and in the labor force, who are observed in one of the 350 MSAs $j$ during a given quarter $t$ in 2002q1-2010q3. All regressions include the following sets of controls: Ownership status X MSA, MSA X time period, Ownership status X time period (results omitted for clarity). The individual characteristic variables, if included, consist of binary indicator variables Female, Nonwhite, Married and Children, as well as continuous variables earn/1000 and age. Education categories, HS, SomeColl, and College+ are all relative to the omitted category of LessthanHS. Standard errors are clustered by MSA to account for general error dependencies within an MSA across time. Coefficient on the ownership*house-price-change variable represents the differential response in outmigration rates to house price changes by owners relative to renters. 
Table 11: Results by Age Group

\begin{tabular}{|c|c|c|c|c|c|c|}
\hline $\begin{array}{l}\text { Population } \\
\text { House Price Variable }\left(H P_{i j t}\right)\end{array}$ & $\begin{array}{c}(1) \\
\mathbf{1 8 - 3 5} \\
\mathbf{n} \_ \text {equity }\end{array}$ & $\begin{array}{c}(2) \\
\mathbf{3 6 - 5 0} \\
\text { n_equity }\end{array}$ & $\begin{array}{c}(3) \\
51-65 \\
\text { n_equity }\end{array}$ & $\begin{array}{c}(4) \\
18-35 \\
\Delta \ln (\text { HPI }) \\
\end{array}$ & $\begin{array}{c}(5) \\
36-50 \\
\Delta \ln (\text { HPI }) \\
\end{array}$ & $\begin{array}{c}(6) \\
51-65 \\
\Delta \ln (\text { HPI }) \\
\end{array}$ \\
\hline Individual Controls Included? & yes & yes & yes & yes & yes & yes \\
\hline$H P_{i j t} X o w n_{i j t}$ & $\begin{array}{c}\beta / \text { s.e. } \\
-0.00197 \\
(0.00109)\end{array}$ & $\begin{array}{c}\beta / \text { s.e. } \\
-0.00182^{*} \\
(0.00078)\end{array}$ & $\begin{array}{c}\beta / \text { s.e. } \\
-0.00290^{* *} \\
(0.00088)\end{array}$ & $\begin{array}{c}\beta / \text { s.e. } \\
0.00626^{* *} \\
(0.00215)\end{array}$ & $\begin{array}{c}\beta / \text { s.e. } \\
0.00407^{*} \\
(0.00172)\end{array}$ & $\begin{array}{c}\beta / \text { s.e. } \\
0.00323^{* *} \\
(0.00112)\end{array}$ \\
\hline$o w n_{i j t}$ & $\begin{array}{l}-0.00318 \\
(0.00451)\end{array}$ & $\begin{array}{l}-0.00448 \\
(0.00302)\end{array}$ & $\begin{array}{c}0.00246 \\
(0.00243)\end{array}$ & $\begin{array}{l}-0.00485 \\
(0.00436)\end{array}$ & $\begin{array}{l}-0.00591 \\
(0.00320)\end{array}$ & $\begin{array}{c}0.00102 \\
(0.00267)\end{array}$ \\
\hline$H P_{i j t}$ & $\begin{array}{r}0.00301^{* *} \\
(0.00092)\end{array}$ & $\begin{array}{c}0.00381^{* * *} \\
(0.00081)\end{array}$ & $\begin{array}{c}0.00501^{* * *} \\
(0.00092)\end{array}$ & $\begin{array}{c}-0.00679^{* *} \\
(0.00192)\end{array}$ & $\begin{array}{c}-0.00713^{* *} \\
(0.00209)\end{array}$ & $\begin{array}{c}-0.00615^{* * *} \\
(0.00123)\end{array}$ \\
\hline
\end{tabular}

Notes: Sample consists of 5,973,937 ACS individuals $i$, either household head or spouse age 18-65, and in the labor force, who are observed in one of the 350 MSAs $j$ during a given quarter $t$ in 2002q1-2010q3. All regressions include the following sets of controls: Ownership status X MSA, MSA X time period, Ownership status X time period (results omitted for clarity). The individual characteristic variables, if included, consist of binary indicator variables Female, Nonwhite, Married and Children, as well as continuous variables earn/1000 and age. Education categories, HS, SomeColl, and College+ are all relative to the omitted category of LessthanHS. Standard errors are clustered by MSA to account for general error dependencies within an MSA across time. Coefficient on the ownership*house-price-change variable represents the differential response in outmigration rates to house price changes by owners relative to renters. 
Table 12: Results by Earnings Quartile

\begin{tabular}{|c|c|c|c|c|c|c|c|c|}
\hline $\begin{array}{l}\text { Population } \\
\text { House Price Variable }\left(H P_{i j t}\right)\end{array}$ & $\begin{array}{c}(1) \\
\text { 1st Quartile } \\
\text { n_equity }\end{array}$ & $\begin{array}{c}\text { (2) } \\
\text { 2nd Quartile } \\
\text { n_equity }\end{array}$ & $\begin{array}{c}\text { (3) } \\
\text { 3rd Quartile } \\
\text { n_equity }\end{array}$ & $\begin{array}{c}(4) \\
\text { 4th Quartile } \\
\text { n_equity }\end{array}$ & \begin{tabular}{c|}
$(5)$ \\
1st Quartile \\
$\Delta \ln (\mathrm{HPI})$ \\
\end{tabular} & \begin{tabular}{|c|}
$(6)$ \\
2nd Quartile \\
$\Delta \ln (\mathrm{HPI})$ \\
\end{tabular} & $\begin{array}{c}(7) \\
\text { 3rd Quartile } \\
\Delta \ln (\text { HPI }) \\
\end{array}$ & $\begin{array}{c}(8) \\
\text { 4th Quartile } \\
\Delta \ln (\text { HPI })\end{array}$ \\
\hline Individual Controls Included? & yes & yes & yes & yes & yes & yes & yes & yes \\
\hline$H P_{i j t}$ Xown $n_{i j t}$ & $\begin{array}{c}\beta / \text { s.e. } \\
-0.00294^{*} \\
(0.00112)\end{array}$ & $\begin{array}{c}\beta / \text { s.e. } \\
-0.00331^{* *} \\
(0.00091)\end{array}$ & $\begin{array}{c}\beta / \text { s.e. } \\
-0.00343^{*} \\
(0.00128)\end{array}$ & $\begin{array}{c}\beta / \text { s.e. } \\
-0.00309^{* *} \\
(0.00103)\end{array}$ & $\begin{array}{c}\beta / \text { s.e. } \\
0.00601^{* * *} \\
(0.00157)\end{array}$ & $\begin{array}{c}\beta / \text { s.e. } \\
0.00537^{* *} \\
(0.00187)\end{array}$ & $\begin{array}{c}\beta / \text { s.e. } \\
0.00538^{* *} \\
(0.00167)\end{array}$ & $\begin{array}{c}\beta / \text { s.e. } \\
0.00532^{* *} \\
(0.00179)\end{array}$ \\
\hline$o w n_{i j t}$ & $\begin{array}{c}-0.00299 \\
(0.00386)\end{array}$ & $\begin{array}{l}-0.00025 \\
(0.00378)\end{array}$ & $\begin{array}{l}-0.00254 \\
(0.00394)\end{array}$ & $\begin{array}{c}0.00260 \\
(0.00324)\end{array}$ & $\begin{array}{l}-0.00527 \\
(0.00382)\end{array}$ & $\begin{array}{l}-0.00213 \\
(0.00373)\end{array}$ & $\begin{array}{l}-0.00447 \\
(0.00398)\end{array}$ & $\begin{array}{c}0.00051 \\
(0.00339)\end{array}$ \\
\hline$H P_{i j t}$ & $\begin{array}{l}0.00386^{* *} \\
(0.00107)\end{array}$ & $\begin{array}{c}0.00376^{* * *} \\
(0.00091)\end{array}$ & $\begin{array}{c}0.00453^{* * *} \\
(0.00105)\end{array}$ & $\begin{array}{c}0.00364^{* * *} \\
(0.00096)\end{array}$ & $\begin{array}{c}-0.00797^{* * *} \\
(0.00212)\end{array}$ & $\begin{array}{c}-0.00708^{* * *} \\
(0.00187)\end{array}$ & $\begin{array}{c}-0.00741^{* * *} \\
(0.00173)\end{array}$ & $\begin{array}{c}-0.00717^{* *} \\
(0.00216)\end{array}$ \\
\hline
\end{tabular}

Notes: Sample consists of 5,973,937 ACS individuals $i$, either household head or spouse age 18-65, and in the labor force, who are observed in one of the 350 MSAs $j$ during a given quarter $t$ in 2002q1-2010q3. All regressions include the following sets of controls: Ownership status X MSA, MSA X time period, Ownership status X time period (results omitted for clarity). The individual characteristic variables, if included, consist of binary indicator variables Female, Nonwhite, Married and Children, as well as continuous variables earn/1000 and age. Education categories, HS, SomeColl, and College+ are all relative to the omitted category of LessthanHS. Standard errors are clustered by MSA to account for general error dependencies within an MSA across time. Coefficient on the ownership*house-price-change variable represents the differential response in outmigration rates to house price changes by owners relative to renters. 
Table 13: Results by Marital Status

\begin{tabular}{|c|c|c|c|c|}
\hline $\begin{array}{l}\text { Population } \\
\text { House Price Variable }\left(H P_{i j t}\right)\end{array}$ & $\begin{array}{c}(1) \\
\text { Unmarried } \\
\mathbf{n} \_ \text {equity }\end{array}$ & $\begin{array}{c}(2) \\
\text { Married } \\
\text { n_equity }\end{array}$ & $\begin{array}{c}(3) \\
\text { Unmarried } \\
\Delta \ln (\text { HPI })\end{array}$ & $\begin{array}{c}(4) \\
\text { Married } \\
\Delta \ln (\text { HPI })\end{array}$ \\
\hline Individual Controls Included? & yes & yes & yes & yes \\
\hline$H P_{i j t} X o w n_{i j t}$ & $\begin{array}{c}\beta / \text { s.e. } \\
-0.00135 \\
(0.00097)\end{array}$ & $\begin{array}{c}\beta / \text { s.e. } \\
-0.00431^{* * *} \\
(0.00077)\end{array}$ & $\begin{array}{c}\beta / \text { s.e. } \\
0.00535^{* *} \\
(0.00166)\end{array}$ & $\begin{array}{c}\beta / \text { s.e. } \\
0.00598^{* * *} \\
(0.00146)\end{array}$ \\
\hline$o w n_{i j t}$ & $\begin{array}{l}-0.00438 \\
(0.00302)\end{array}$ & $\begin{array}{l}-0.00104 \\
(0.00246)\end{array}$ & $\begin{array}{l}-0.00627^{*} \\
(0.00299)\end{array}$ & $\begin{array}{l}-0.00319 \\
(0.00243)\end{array}$ \\
\hline$H P_{i j t}$ & $\begin{array}{c}0.00285^{* *} \\
(0.00091)\end{array}$ & $\begin{array}{c}0.00466^{* * *} \\
(0.00080)\end{array}$ & $\begin{array}{c}-0.00659^{* *} \\
(0.00196)\end{array}$ & $\begin{array}{c}-0.00791^{* * *} \\
(0.00180)\end{array}$ \\
\hline
\end{tabular}

Notes: Sample consists of 5,973,937 ACS individuals $i$, either household head or spouse age 18-65, and in the labor force, who are observed in one of the 350 MSAs $j$ during a given quarter $t$ in 2002q1-2010q3. All regressions include the following sets of controls: Ownership status X MSA, MSA X time period, Ownership status X time period (results omitted for clarity). The individual characteristic variables, if included, consist of binary indicator variables Female, Nonwhite, Married and Children, as well as continuous variables earn/1000 and age. Education categories, HS, SomeColl, and College+ are all relative to the omitted category of LessthanHS. Standard errors are clustered by MSA to account for general error dependencies within an MSA across time. Coefficient on the ownership*house-price-change variable represents the differential response in outmigration rates to house price changes by owners relative to renters. 
Table 14: Results by Presence of Children

\begin{tabular}{l|c|c|c|c}
\hline \hline Population & $\begin{array}{c}(1) \\
\text { No Children } \\
\text { n_equity }\end{array}$ & $\begin{array}{c}(2) \\
\text { Children } \\
\text { n_equity }\end{array}$ & $\begin{array}{c}(3) \\
\text { No Children } \\
\Delta \ln (\mathbf{H P I})\end{array}$ & $\begin{array}{c}(4) \\
\text { Children } \\
\Delta \ln (\mathbf{H P I})\end{array}$ \\
\hline Individual Controls Included? & yes & yes & yes & yes \\
\hline & $\beta /$ s.e. & $\beta /$ s.e. & $\beta /$ s.e. & $\beta /$ s.e. \\
$H P_{i j t} X_{\text {own }} n_{i j t}$ & $-0.00463^{* * *}$ & -0.00150 & $0.00737^{* * *}$ & $0.00373^{* *}$ \\
$H P_{i j t}$ & $(0.00087)$ & $(0.00094)$ & $(0.00170)$ & $(0.00129)$ \\
& -0.00096 & -0.00262 & $-0.00384^{*}$ & -0.00378 \\
own & $(0.00207)$ & $(0.00303)$ & $(0.00184)$ & $(0.00313)$ \\
& $0.00463^{* * *}$ & $0.00265^{*}$ & $-0.00818^{* * *}$ & $-0.00621^{* * *}$ \\
${ }^{*} \mathrm{p} \leq 0.05,{ }^{* *} \mathrm{p} \leq 0.01,{ }^{* * *} \mathrm{p} \leq 0.001$ & $(0.00081)$ & $(0.00097)$ & $(0.00204)$ & $(0.00168)$ \\
\hline
\end{tabular}

Notes: Sample consists of 5,973,937 ACS individuals $i$, either household head or spouse age 18-65, and in the labor force, who are observed in one of the 350 MSAs $j$ during a given quarter $t$ in 2002q1-2010q3. All regressions include the following sets of controls: Ownership status X MSA, MSA X time period, Ownership status X time period (results omitted for clarity). The individual characteristic variables, if included, consist of binary indicator variables Female, Nonwhite, Married and Children, as well as continuous variables earn/1000 and age. Education categories, HS, SomeColl, and College+ are all relative to the omitted category of LessthanHS. Standard errors are clustered by MSA to account for general error dependencies within an MSA across time. Coefficient on the ownership*house-price-change variable represents the differential response in outmigration rates to house price changes by owners relative to renters. 
Table 15: Results by Education Group

\begin{tabular}{|c|c|c|c|c|c|c|c|c|}
\hline $\begin{array}{l}\text { Population } \\
\text { House Price Variable }\left(H P_{i j t}\right)\end{array}$ & $\begin{array}{c}(1) \\
\text { Less than HS } \\
\text { n_equity }\end{array}$ & $\begin{array}{c}(2) \\
\text { HS } \\
\text { n_equity }\end{array}$ & $\begin{array}{c}(3) \\
\text { Some Coll } \\
\text { n_equity }\end{array}$ & $\begin{array}{c}(4) \\
\text { Coll }+ \\
\text { n_equity }\end{array}$ & $\begin{array}{c}(5) \\
\text { Less than HS } \\
\Delta \ln (\mathrm{HPI})\end{array}$ & $\begin{array}{c}(6) \\
\text { HS } \\
\Delta \ln (\text { HPI }) \\
\end{array}$ & $\begin{array}{c}(7) \\
\text { Some Coll } \\
\Delta \ln (\text { HPI }) \\
\end{array}$ & $\begin{array}{c}\text { (8) } \\
\text { Coll }+ \\
\Delta \ln (\text { HPI })\end{array}$ \\
\hline Individual Controls Included? & yes & yes & yes & yes & yes & yes & yes & yes \\
\hline$H P_{i j t} X_{o w n} n_{i j t}$ & $\begin{array}{c}\beta / \text { s.e. } \\
-0.00286 \\
(0.00158)\end{array}$ & $\begin{array}{c}\beta / \text { s.e. } \\
-0.00217 \\
(0.00119)\end{array}$ & $\begin{array}{c}\beta / \text { s.e. } \\
-0.00328^{* *} \\
(0.00101)\end{array}$ & $\begin{array}{c}\beta / \text { s.e. } \\
-0.00416^{* * *} \\
(0.00100)\end{array}$ & $\begin{array}{c}\beta / \text { s.e. } \\
0.00533^{*} \\
(0.00199)\end{array}$ & $\begin{array}{c}\beta / \text { s.e. } \\
0.00422^{*} \\
(0.00204)\end{array}$ & $\begin{array}{c}\beta / \text { s.e. } \\
0.00527^{* *} \\
(0.00187)\end{array}$ & $\begin{array}{c}\beta / \text { s.e. } \\
0.00771^{* * *} \\
(0.00177)\end{array}$ \\
\hline$o w n_{i j t}$ & $\begin{array}{l}-0.00899 \\
(0.00608)\end{array}$ & $\begin{array}{l}-0.00036 \\
(0.00427)\end{array}$ & $\begin{array}{c}0.00611 \\
(0.00360)\end{array}$ & $\begin{array}{l}-0.00562 \\
(0.00279)\end{array}$ & $\begin{array}{l}-0.01112 \\
(0.00612)\end{array}$ & $\begin{array}{l}-0.00186 \\
(0.00441)\end{array}$ & $\begin{array}{c}0.00423 \\
(0.00346)\end{array}$ & $\begin{array}{c}-0.00849^{* *} \\
(0.00283)\end{array}$ \\
\hline$H P_{i j t}$ & $\begin{array}{l}0.00314^{*} \\
(0.00137)\end{array}$ & $\begin{array}{l}0.00320^{* *} \\
(0.00098)\end{array}$ & $\begin{array}{c}0.00371^{* * *} \\
(0.00086)\end{array}$ & $\begin{array}{c}0.00473^{* * *} * \\
(0.00099)\end{array}$ & $\begin{array}{c}-0.00642^{* * *} \\
(0.00156)\end{array}$ & $\begin{array}{r}-0.00597^{*} \\
(0.00218)\end{array}$ & $\begin{array}{c}-0.00697^{* *} \\
(0.00219)\end{array}$ & $\begin{array}{c}-0.00947^{* * *} \\
(0.00222)\end{array}$ \\
\hline
\end{tabular}

Notes: Sample consists of 5,973,937 ACS individuals $i$, either household head or spouse age 18-65, and in the labor force, who are observed in one of the 350 MSAs $j$ during a given quarter $t$ in 2002q1-2010q3. All regressions include the following sets of controls: Ownership status X MSA, MSA X time period, Ownership status X time period (results omitted for clarity). The individual characteristic variables, if included, consist of binary indicator variables Female, Nonwhite, Married and Children, as well as continuous variables earn/1000 and age. Education categories, HS, SomeColl, and College+ are all relative to the omitted category of LessthanHS. Standard errors are clustered by MSA to account for general error dependencies within an MSA across time. Coefficient on the ownership*house-price-change variable represents the differential response in outmigration rates to house price changes by owners relative to renters. 